\title{
Lymphocyte Function-Associated Antigen 3
}

National Cancer Institute

\section{Source}

National Cancer Institute. Lymphocyte Function-Associated Antigen 3. NCI Thesaurus. Code $\mathrm{C17403.}$

Lymphocyte function-associated antigen 3 ( $250 \mathrm{aa}, \sim 28 \mathrm{kDa}$ ) is encoded by the human CD58 gene. This protein is involved in the adhesion and activation of T-lymphocytes. 